\title{
ENVIRONMENTALLY INDUCED CHANGES IN RIBOSOMAL RNA CISTRON NUMBER IN FLAX
}

\author{
C. A. CULLIS \\ John Innes Institute, Colney Lane, Norwich NR4 7UH
}

Received 4.ix.75

\begin{abstract}
SUMmary
The ribosomal RNA cistron number has been determined in a number of environmentally induced genotrophs of the flax variety "Stormont Cirrus". The large genotrophs and the plastic variety were shown to have approximately the same number of ribosomal RNA cistrons while the small genotrophs had a reduced number of cistrons. There was no correlation between ribosomal cistron number and either nuclear DNA content of the genotrophs or plant weight.
\end{abstract}

\section{INTRODUCTION}

Heritable changes in plant weight have been induced in certain flax varieties by different environments (Durrant, 1962, 1971). In the variety "Stormont Cirrus" a large stable genotroph, L, and a small stable genotroph, S, have been induced from the original plastic line, $\mathrm{Pl}$, by an imbalance of nitrogen and phosphate fertiliser respectively (Durrant, 1971). $\mathrm{L}$ can be up to six times the plant weight of $\mathrm{S}$ with $\mathrm{Pl}$ having a plant weight intermediate between $\mathrm{L}$ and $\mathrm{S}$.

In addition to the plant weight differences, the two stable induced genotrophs differed from each other and $\mathrm{Pl}$ in a number of properties. $\mathrm{L}$ was taller than $\mathrm{S}$ but shorter than $\mathrm{Pl}$. L had up to 16 per cent more nuclear DNA than S with Pl having an intermediate amount (Evans, Durrant and Rees, 1966). Pl and S have hairy septa of the seed capsule while L has hairless septa (Durrant and Nicholas, 1970). L and Pl have been shown to have similar numbers of ribosomal RNA cistrons while $\mathrm{S}$ had a reduced number (Timmis and Ingle, 1973; Cullis, 1975). The isozyme band pattern of peroxidase and acid phosphatase has been shown to be different between L, S and Pl (Cullis and Kolodynska, 1975).

Under certain circumstances the induced changes in the genotrophs have been shown to become unstable (Joarder et al., 1975; Durrant and Jones, 1971). In some of these instances, types were obtained which still showed the full six-fold plant weight differences but in which there was no nuclear DNA amount difference. These lines were called nuclear reversion lines (Durrant and Jones, 1971; Joarder et al., 1975). Large and small genotrophs, as defined by plant weight differences, which differed in other respects from lines also designated large and small on the basis of plant weight, have been obtained in one induction experiment (Durrant, 1971).

The ribosomal RNA cistron number was determined in two independently induced large and small genotrophs, the plastic variety and four nuclear reversion types to determine the extent of the variation of this character and its correlation with other induced characteristics. 


\section{Materials and methods}

(i) Origin and description of genotrophs

$P l$ variety. "Stormont Cirrus" was obtained from Dr A. Durrant and also a further sample from the Ministry of Agriculture, Northern Ireland.

$L_{1}$ and $S_{1}$ genotrophs. Seed of these genotrophs, induced in 1954, were obtained from Dr A. Durrant. $\mathrm{L}_{1}$ had 14 per cent more nuclear DNA than $\mathrm{S}_{1}$, and $\mathrm{L}_{1}$ could be up to six times the plant weight of $\mathrm{S}_{1}$. $\mathrm{L}_{1}$ had hairless septa in the seed capsule while $S_{1}$ had hairy septa (Durrant and Nicholas, 1970).

$L_{3}$ and $S_{3}$ genotrophs. These were derived from $L_{1}$ and $S_{1}$ above by growing out-of-doors for three generations. Both have the same nuclear DNA amount as that normally found in the Pl variety (Durrant and Jones 1971; Joarder et al., 1975). $\quad \mathrm{L}_{3}$ and $\mathrm{S}_{3}$ are phenotypically the same as $\mathrm{L}_{1}$ and $\mathrm{S}_{1}$ respectively.

$L_{6}$ and $S_{6}$ genotrophs. These were derived from $\mathrm{L}_{3}$ and $\mathrm{S}_{3}$ respectively by a further three generations' growth out-of-doors. Both $\mathrm{L}_{6}$ and $\mathrm{S}_{6}$ have the same nuclear DNA amount as the $\mathrm{S}_{1}$ genotroph described above (Durrant, personal communication). $\quad \mathrm{L}_{6}$ is phenotypically the same as $\mathrm{S}_{6}$ and both appear the same as $\mathrm{S}_{1}$.

$L^{H}$ and $S^{h}$ genotrophs. These were obtained in an independent induction experiment in 1961 . $\mathrm{L}^{\mathrm{H}}$ has 10 per cent more nuclear DNA than $\mathrm{S}^{\mathrm{h}}$. $\mathrm{L}^{\mathrm{H}}$ has hairy septa while $S^{h}$ has hairless septa. $S^{h}$ is taller than the $S_{1}$ genotroph induced in 1954 (A. Durrant, personal communication).

\section{(ii) $D \mathcal{N} A$ measurements}

Apical buds were fixed in ethanol-acetic acid $(3: 1, \mathrm{v} / \mathrm{v})$ for 24 hours. They were then hydrolysed with $5 \mathrm{~N}-\mathrm{HCl}$ for 50 minutes at $20^{\circ} \mathrm{C}$, stained with Schiffs reagent for 2 hours, washed three times with sulphite water and squashed in glycerol. The amount of dye bound was measured on a Vickers M85 microdensitometer fitted with a crushing condenser.

\section{(iii) Nuclear preparation}

Nuclear preparations from leaves were made by a 15-second homogenisation of the tissue in an atomix liquidiser in a medium containing $250 \mathrm{mM}$

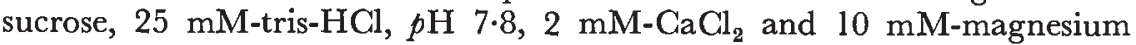
acetate $(5 \mathrm{vol} / \mathrm{g}$ tissue). The slurry was filtered through four layers of muslin and the nuclear and chloroplast material sedimented at $2000 \mathrm{~g}$ for 10 minutes. The chloroplasts were solubilised by the addition of Triton X-100 ( 2 per cent final concentration) to the pellet resuspended in the homogenisation medium. The nuclear material was recovered by centrifugation at $2500 \mathrm{~g}$ for 15 minutes and washed with the Triton medium until no traces of green remained.

\section{(iv) $D \mathcal{N} A$ preparation}

The nuclear pellet was resuspended in $50 \mathrm{mM}-\mathrm{NaCl}, 10 \mathrm{mM}$-tris- $\mathrm{HCl}$, $0 \cdot 1 \mathrm{M}$-EDTA, 1 per cent $(\mathrm{w} / \mathrm{v})$ sodium lauryl sulphate, $p \mathrm{H} 8 \cdot 0$. The salt concentration was increased to $0.5 \mathrm{M}-\mathrm{NaCl}$ and the mixture shaken with an equal volume of chloroform-isoamyl alcohol $(24: 1 \mathrm{v} / \mathrm{v})$ for 10 minutes. 
The aqueous layer was removed after centrifugation at $2500 \mathrm{~g}$ for 10 minutes and the DNA spooled following the addition of two volumes of ethanol. The precipitate was redissolved in $0.1 \times \mathrm{SSC}$ (SSC:0.15 M-NaCl, 0.015 Mtrisodium citrate, $p \mathrm{H} \mathrm{7.2)}$ and the solution made up to $1 \times$ SSC. The DNA was purified by digestion of the preparation by deoxyribonuclease-free RNase $(50 \mu \mathrm{g} / \mathrm{ml})$ and $\alpha$-amylase $(50 \mu \mathrm{g} / \mathrm{ml})$ for 30 minutes at $37^{\circ} \mathrm{C}$, followed by digestion with pronase $(1 \mathrm{mg} / \mathrm{ml})$ for 1 hour. The mixture was then deproteinised with chloroform-isoamyl alcohol and the DNA precipitated from the aqueous layer with two volumes of ethanol.

Total DNA was prepared from leaves by grinding in $3 \times \mathrm{SSC}, 0 \cdot 1 \mathrm{M}$ EDTA, $p \mathrm{H} 8 \cdot 0,0 \cdot 1 \mathrm{M}$-diethyldithiocarbamate $(2 \mathrm{ml} / \mathrm{gm}$ tissue $)$, then adding sodium lauryl sulphate to $l$ per cent $(\mathrm{w} / \mathrm{v})$ followed by the procedure for the nuclear pellet after dissolving in the detergent medium.

Prior to hybridisation the DNA was purified by preparative $\mathrm{CsCl}$ centrifugation. Approximately $200 \mu \mathrm{g}$ DNA was centrifuged to equilibrium in $\mathrm{CsCl}$ (density $1.700 \mathrm{~g} \mathrm{~cm}^{-3}$ ) at $40,000 \mathrm{rpm}$ for 44 hours at $25^{\circ}$ in a Beckman 50 rotor.

\section{(v) Preparation and fractionation of labelled $R \mathcal{N} A$}

Peas were surface sterilised and germinated under sterile conditions for 72 hours. The roots of the intact plants were then immersed in water containing $200 \mu \mathrm{Ci} / \mathrm{ml}^{3} \mathrm{H}$-uridine for a further 72 hours. The root tips were

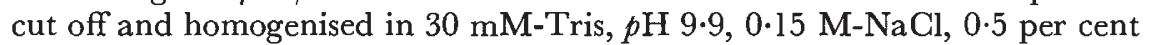
sarcosyl. The mixture was deproteinised with an equal volume of phenol/ cresol ( $500 \mathrm{~g}$ phenol, $70 \mathrm{ml}$ m-cresol, $0.5 \mathrm{~g}$ 8-hydroxyquinoline, $55 \mathrm{ml}$ water) and the nucleic acids precipitated with 95 per cent ethanol containing $0.1 \mathrm{M}$-sodium acetate, $p \mathrm{H} 5 \cdot 5$. The RNA was fractionated on 2.4 per cent polyacrylamide gels and the regions containing the two large ribosomal RNAs were sliced out and extracted separately with a medium containing $3 \mathrm{ml} 0.15 \mathrm{M}-\mathrm{NaCl}, 0.1 \mathrm{ml} 10$ per cent sodium lauryl sulphate, $0.1 \mathrm{ml}$ bentonite $(40-50 \mathrm{mg} / \mathrm{ml})$ and $3 \mathrm{ml}$ phenol/cresol solution. After centrifugation at $3000 \mathrm{~g}$ for 10 minutes the aqueous layer was removed, extracted with ether and then used for hybridisation.

The specific activities (cpm/ $\mathrm{g}$ RNA) of the RNA preparations used were: (a) 23,200; (b) 15,600 ; (c) 12,300 .

\section{(vi) Hybridisation}

DNA dissolved in $0 \cdot 1 \times \mathrm{SSC}$ at $30-50 \mu \mathrm{g} / \mathrm{ml}$ was denatured by the addition of $0 \cdot 1$ volume of $1 \mathrm{~N}-\mathrm{NaOH}$. After 15 minutes at room temperature the solution was neutralised by the addition of 0.1 volume of $1 \mathrm{~N}-\mathrm{HCl}$ and the salt concentration increased by the addition of 0.4 volume of $24 \times \mathrm{SSC}$. The denatured DNA was loaded on to a $13 \mathrm{~mm}$ HAWP millipore filter (15-20 $\mu \mathrm{g}$ DNA/filter). The filter was air dried and finally dried in an oven at $80^{\circ} \mathrm{C}$ for 2 hours before use. The DNA filters were incubated separately with the labelled RNA in $6 \times \mathrm{SSC}$ at $70^{\circ} \mathrm{C}$ for 4 hours in a volume of $1 \mathrm{ml}$, removed from the RNA and washed successively in $6 \times \mathrm{SSC}$, three changes of $2 \times \mathrm{SSC}$ containing $\mathrm{RNAse}(10 \mu \mathrm{g} / \mathrm{ml})$, and then dried at $80^{\circ} \mathrm{C}$. The radioactivity bound was determined by scintillation counting with 2,4-diphenyloxazole (4 g/litre) +1,4-di-[2-(5-phenyloxazole)benzene] $0.25 \mathrm{~g} /$ litre) in 
toluene. After counting, the DNA content of the filters was determined by acid hydrolysis (Brown and Weber, 1968).

At least two independent DNA preparations of all the samples were used, and duplicate filters of each DNA were incubated in each experiment. All measurements were corrected for the background of filters lacking DNA, but which had been taken through all the stages of the hybridisation procedure. The radioactivity bound to blank filters was always less than 0.02 per cent of the added radioactivity. Filters containing $E$. coli DNA were also incorporated in certain experiments. The binding of the pea rRNA to this heterologous DNA was less than 2 per cent of the lowest value obtained for any of the flax DNAs.

The retention of DNA by the filters was normally greater than 95 per cent. In one experiment the retention was only 60 per cent of the DNA but the same hybridisation proportions were obtained.

It has been shown that the extent of hybridisation depends on whether the $1.3 \times 10^{6}$ daltons rRNA or the $0.7 \times 10^{6}$ daltons rRNA are used (Scott and Ingle, 1973; Cullis, 1975). For the comparison of the various lines here a 2:1 mixture of the two rRNAs was used as this gave essentially the same relative values as those obtained for the $1.3 \times 10^{6}$ daltons rRNA alone (Cullis, 1975).

The extent of hybridisation with various rRNA concentrations up to $5 \mu \mathrm{g} / \mathrm{ml}$ was determined. No increase in the extent of hybridisation was observed at concentrations above $1.5 \mu \mathrm{g} / \mathrm{ml}$ and a concentration of $3 \mu \mathrm{g} / \mathrm{ml}$ was used in comparing DNAs from different lines.

\section{RESUltS AND Discussion}

The nuclear DNA values given in table 1 were determined by 1жeasuring 10 metaphases on four slides for each line. The results obtained were in agreement with the values reported by Joarder et al. (1975) for the lines $\mathrm{L}_{1}, \mathrm{~S}_{1}, \mathrm{~L}_{3}, \mathrm{~S}_{3}$ while the values for $\mathrm{L}_{6}, \mathrm{~S}_{6}, \mathrm{~L}^{\mathrm{H}}$, $\mathrm{S}^{\mathrm{h}}$ were in agreement with the values obtained by Durrant (personal communication).

The proportion of the DNA complementary to ribosomal RNA (rDNA) for the different lines is given in table 1 . The values obtained for the two samples of $\mathrm{Pl}$ were not different and have been amalgamated.

The rDNA proportions of the three lines, $\mathrm{L}_{1}, \mathrm{~L}_{3}, \mathrm{~L}^{\mathrm{H}}$, which are classified

TABLE 1

Ribosomal RNA cistron number in flax genotrophs. DNA hybridised with a $2: 1$ mixture of $1 \cdot 3 \times 10^{6}$ dalton and $0.7 \times 10^{6}$ dalton $r R \mathcal{N} A s$

\begin{tabular}{|c|c|c|c|c|}
\hline Genotroph & Phenotype* & $\begin{array}{l}\text { DNA content } 10^{-12} \mathrm{~g} \\
\text { per } 2 \mathrm{C} \text { nucleus }\end{array}$ & $\%$ rDNA & $\begin{array}{l}\text { Number ribosomal } \\
\text { RNA genes }\end{array}$ \\
\hline Pl & - & $1 \cdot 40$ & $0.63 \pm 0.04$ & 2660 \\
\hline $\mathrm{L}_{1}$ & Large & 1.53 & $0.51 \pm 0.03$ & 2370 \\
\hline $\mathrm{L}_{3}$ & Large & $1 \cdot 42$ & $0.58 \pm 0.03$ & 2440 \\
\hline $\mathrm{L}_{6}$ & Small & $1 \cdot 34$ & $0.26 \pm 0.03$ & 1050 \\
\hline $\mathrm{L}^{\mathrm{H}}$ & Large & 1.47 & $0.58 \pm 0.05$ & 2570 \\
\hline $\mathrm{S}_{1}$ & Small & $1 \cdot 32$ & $0.36 \pm 0.02$ & 1430 \\
\hline $\mathrm{S}_{3}$ & Small & 1.40 & $0.38 \pm 0 \cdot 02$ & 1600 \\
\hline $\mathrm{S}_{6}$ & Small & $1 \cdot 33$ & $0.40 \pm 0.04$ & 1610 \\
\hline$S^{h}$ & Small & $1 \cdot 36$ & $0.39 \pm 0.03$ & 1570 \\
\hline
\end{tabular}

* Determined on the basis of plant weight. 
as the large genotrophs on a plant weight basis, differed slightly, with $\mathrm{L}_{1}$ being lower than the other two lines. When these values were corrected for the nuclear DNA amount differences they were not significantly different from each other, although all were still lower than the value obtained for Pl.

A difference was observed in the rDNA proportions of the lines showing the small plant weight phenotype. Four of these lines, $S_{1}, S_{3}, S_{6}$ and $S^{h}$ all had a similar rDNA proportion but that of $\mathrm{L}_{6}$ was much lower. When the nuclear DNA amounts were taken into consideration, $\mathrm{L}_{6}$ had 32 per cent fewer ribosomal cistrons than the mean value of the other four small lines.

The results in table 1 show that there is variation in the ribosomal cistron number in the different lines of flax derived from the original Pl variety "Stormont Cirrus" and that changes can occur in a single generation. In a number of other species the number of ribosomal genes per nucleolar organiser has been shown to vary and appears to be under genetic control. The number of rRNA genes in aneuploid lines of hyacinth (Timmis et al., 1972) and hexaploid wheat (Flavell and Smith, 1974) have been shown to be affected by chromosomes other than the nucleolus organising chromosomes. In Drosophila the rRNA genes can vary over short periods of time (Tartof, 1971), while in Xenopus, individuals with reduced rRNA genes are frequent in natural populations and in matings between " normal " parents (Miller and Gurdon, 1970).

A correlation between reduced ribosomal cistron number and the small plant weight phenotype was observed. However, within the group of small types, one line had 30 per cent fewer ribosomal cistrons than the others. Biochemical and genetic analyses of the bobbed mutants in Drosophila suggest that variation in the rRNA gene number may be reflected in the vigour of the phenotype (Ritossa and Scala, 1969). A change in vigour due to a reduction in ribosomal cistron number could account for the small phenotype but the converse is not true, i.e. the large type has approximately the same number of cistrons as the plastic variety. Thus the rRNA cistron number alone is not sufficient to differentiate unambiguously between the plastic type and the high and low plant weight lines.

There was no correlation between the ribosomal cistron number and the nuclear DNA amount (table 1). Thus the variation in total nuclear DNA and rDNA must be independently controlled. Independent control of parts of the genome has been described for rDNA, euchromatin and heterochromatin in the polytene cells of Drosophila (Spear, 1974), rDNA in Phaseolus coccineus (Lima-de-Faria et al., 1975) and peas (Cullis and Davies, 1975) and for satellite DNA in melon (Pearson et al., 1974). From studies on nucleolar mutants in Xenopus, which have reduced nuclear DNA amounts (Amaldi, Lava-Sanchez and Buongiorno-Nardelli, 1973), only a small percentage of which was accounted for by the rRNA genes, it was suggested that a portion of the genome was made up of families of sequences which were genetically regulated as a geometric series. If such families occur in the flax genotrophs studied here then the different nuclear DNA lines could occur by the differential regulation of such families under specific environmental conditions. Certain of the families of sequences could be those of intermediate repetition found in $\mathrm{L}_{1}$ but not in $\mathrm{Pl}$ or $\mathrm{S}_{1}$ (Cullis, 1973, 1975). Only certain of these families may be co-regulated with the ribosomal genes, giving the observed lack of correlation between the nuclear DNA amount and a ribosomal cistron number. 
A variety of phenotypic effects, including variation in plant weight, plant height, nuclear DNA content, hairyness of capsule septa, peroxidase and acid phosphatase isozyme band patterns and rRNA cistron number, have been observed in the environmental induction of flax genotrophs. Not all of these effects are associated with each other in the induced types suggesting that their expression can be independently controlled. Thus a given environment need not induce, stabilise or revert all the various characteristics equally. In particular it may be possible to define environments in which each of the characteristics is altered independently; this situation has already been described for the nuclear DNA amount (Durrant and Jones, 1971; Joarder et al., 1975). Where only a single characteristic varies it may be possible to determine the developmental stage at which that heritable change occurs and the control of the variation. In addition a further characterisation of the DNA of the different genotrophs would elucidate which nuclear changes determined the variable phenotypic characteristics observed in the genotrophs.

Acknowledgments.-I am grateful to Dr A. Durrant for the flax seed and to Mrs V. Brewster for her excellent technical assistance.

\section{References}

AMALdi, F., LAVA-SANGHez, P. A., AND BUONGIORNo-NARdelli, M. 1973. Nuclear DNA content variability in Xenopus laevis. A reduncancy regulation common to all gene families. Nature, 242, 615-617.

BROWN, D. D., AND WEBER, c. S. 1968. Gene linkage by RNA-DNA hybridisation. I. Unique DNA sequences homologous to $4 \mathrm{~S}, 5 \mathrm{~S}$ and rRNAs. 7. Molec. Biol., 34, 661-680.

CUllis, c. A. 1973. DNA differences between flax genotrophs. Nature, 243, 515-516.

Cullis, C. A. 1975. Environmentally induced DNA changes in flax. In Modification of the Information Content of Plant Cells, eds. R. Markham, D. R. Davies, D. A. Hopwood, and R. W. Horne. North Holland, Amsterdam.

CUllis, C. A., AND DAVIES, D. R. 1975. Ribosomal DNA amounts in Pisum sativum. Genetics 81, 485-492.

CUllis, C. A., AND xolodyNskA, x. 1975. Variation in the isozymes of flax (Linum usitatissimum) genotrophs. Biochem. Genet., 13, 687-697.

DURRANT, A. 1962. The environmental induction of heritable changes in Linum. Heredity, 17, 27-61.

DURrant, A. 1971. The induction and growth of flax genotrophs. Heredity, 27, 277-298.

DURRANT, A., AND JONES, T. W. A. 1971. Reversion of induced changes in amount of nuclear DNA in Linum. Heredity, 27, 431-439.

Durrant, A., ANd nicholas, D. B. 1970. An unstable gene in flax. Heredity, 25, 515-527.

EVANS, G. M., DURRANT, A., AND REES, H. 1966. Associated nuclear changes in the induction of flax genotrophs. Nature, 212, 697-699.

FLAVELL, R. B., AND SMITH, D. B. 1974. Variation in the nucleolar organiser rRNA gene multiplicity in wheat and rye. Chromosoma (Berl.), 47, 327-334.

JOARDER, I. O., AL-SAHEAL, V., BEGUM, J., AND DURRANT, A. 1975. Environments inducing changes in amount of DNA in flax. Heredity, 34, 247-253.

lima-de-FARIA, A., PERo, R., AVANZi, s., DURANTe, M., STAHLe, U., D'AMATo, F., AND GRANSTROM, H. 1975. Relation between ribosomal RNA genes and the DNA satellites of Phaseolus coccineus. Hereditas, 79, 5-20.

MILlER, L., AND GURDON, J. B. 1970. Mutations affecting the size of the nucleolus in Xenopus laevis. Nature, 227, 1108-1110.

PEARSON, G. G., TIMMIS, J. N., AND INGLE, J. 1974. The differential replication of DNA during plant development. Chromosoma (Berl.), 45, 281-294.

RITOSSA, F. M., AND SCALA, G. 1969. Equilibrium variations in the redundancy of rDNA in Drosophila melanogaster. Genet. Suppl., 61, 305-318.

SCOTT, N. s., AND INGLE, J. 1973. The genes for cytoplasmic ribosomal ribonucleic acid in higher plants. Plant Physiol., 51, 677-684. 
SPEAR, B. B. 1974. The genes for ribosomal RNA in diploid and polytene chromosomes of Drosophila melanogaster. Chromosoma (Berl.), 48, 159-180.

TARTOF, K. D. 1971. Increasing the multiplicity of ribosomal RNA genes in Drosophila melanogaster. Science, 171, 294-297.

TIMMIS, J. N., AND INGLE, J. 1973. Environmentally induced changes in rRNA gene redundancy. Nature, New Biology, 244, 235-236.

TIMMIS, J. N., SINCLAIR, J., AND INGLE, J. 1972. Ribosomal RNA genes in euploids and aneuploids of hyacinth. Cell Differentiation, 1, 335-339. 